\title{
SOLAR 1.1: DEVELOPMENT OF SOFTWARE FOR SELECTING COMMERCIALLY AVAILABLE PHOTOVOLTAIC PANELS, INCLUDING THE ECONOMIC ANALYSIS
}

\author{
P. Laranci ${ }^{\mathrm{a}}$, \\ J. L. Silveira ${ }^{\mathbf{b}}$, \\ and W. Q. Lamas ${ }^{\mathrm{b}}$ \\ ${ }^{a}$ Università degli Studi di Perugia \\ Dipartimento di Ingegneria Industriale \\ DII UNIPG \\ Via Duranti 67 \\ 06125 Perugia, Italia \\ paolo.laranci@unipg.it \\ ${ }^{\mathrm{b}}$ Universidade Estadual Paulista \\ Faculdade de Engenharia \\ Departamento de Energia \\ Av. Dr. Ariberto Pereira da Cunha, 333 \\ 12516-410, Guaratinguetá, São Paulo, Brasil \\ \{joseluz,wendell\}@ @eg.unesp.br
}

\begin{abstract}
Photovoltaic energy represents an opportunity to produce electricity in a clean manner. It can be applied in all world places, in particular in the developing countries, where there are places where electricity grids are unreliable or non-existent and is inconvenient to make investments in a grid expansion. In remote locations photovoltaic power supplies often the most economic and cleaner option to produce electric energy. In addition, many developing countries have high radiation levels year round because of their latitude. The software SOLAR 1.1 was developed with purpose of helping the choice of photovoltaic panels available commercially including electric needs calculation for the installation. This new version of program also help to conduce the economic analysis for grid connected or stand alone photovoltaic systems for the choice of convenient values of interest rate and payback period. In this version of the software is possible to select the language among English, Italian and Portuguese. The software choices the panels in its archive that contains more of 250 types of photovoltaic modules made by 35 producers. The selection provides as output three modules, the cheapest for each cell type: monocrystalline, multicrystalline and amorphous. The software archive can be updated adding new item or editing the inserted items. The economic analysis can be operated by SOLAR 1.1 in each of the chosen panels. This analysis gives as output all the values of the costs in the photovoltaic system and the diagrams with the electricity cost and the expected annual saving trend with variation of the amortisation period and for different values of the interest rate and the governmental subsidy rate.
\end{abstract}

Keywords: economic analysis, photovoltaic cell, photovoltaic systems, solar radiation.

\section{NOMENCLATURE}

\section{A PV panel surface, $\mathrm{m}^{2}$}

$\mathrm{C}_{\mathrm{b}} \quad$ cost of battery, US\$

$\mathrm{C}_{\mathrm{d}} \quad$ cost of acquisition and installation of peripheral components, US\$

$\mathrm{C}_{\mathrm{el}} \quad$ cost of electric energy production in the photovoltaic system, US $\$ / \mathrm{kWh}$

$\mathrm{C}_{\mathrm{el}} \quad$ cost of electricity production in the PV system, US\$/kWh

$\mathrm{C}_{\mathrm{m}} \quad$ cost of a photovoltaic module, US\$

$\mathrm{C}_{\mathrm{ma}} \quad$ maintenance cost, US $\$ / \mathrm{kWh}$

$\mathrm{C}_{\text {mex }} \quad$ marginal cost of expansion of the electric energy offer, US $\$ / \mathrm{kWh}$

$\mathrm{C}_{\mathrm{op}} \quad$ operation costs, US $\$ / \mathrm{kWh}$

$\mathrm{E}$ daily demand energy, Wh/day

$\mathrm{E}_{\mathrm{p}} \quad$ produced energy in a year, $\mathrm{kWh} /$ year

$\mathrm{F} \quad$ annuity factor, year ${ }^{-1}$

$\mathrm{H}_{\mathrm{i}} \quad$ number of daily operation of the i-load, $\mathrm{h} /$ day

$\mathrm{I}_{\mathrm{pl}} \quad$ total investment in the plant, US\$

$\mathrm{K}$ amortisation period, years

$\mathrm{n}_{\mathrm{i}} \quad$ number of the i-load $\mathrm{n}_{\mathrm{m}} \quad$ number of module in the PV system

$\mathrm{n}_{\mathrm{w}} \quad$ number of working months, generally 13

$\mathrm{n}_{\mathrm{tec}} \quad$ number of technicians needed for the operation

$\mathrm{P}_{\mathrm{el}} \quad$ electric tax, US $\$ / \mathrm{kWh}$

$\mathrm{P}_{\mathrm{i}} \quad$ power of the i-load, $\mathrm{W}$

$\mathrm{P}_{\mathrm{p}} \quad$ peak power, $\mathrm{W}_{\mathrm{p}}$

$\mathrm{R}$ annual mean daily insolation, $\mathrm{Wh} / \mathrm{m}^{2}$.day

$\mathrm{R}$ annual interest rate, \%

$\mathrm{R}_{\mathrm{A}} \quad$ annual insolation, $\mathrm{kWh} / \mathrm{m}^{2}$.year

$\mathrm{S}_{\mathrm{al}}$ monthly salary of a technicians, US\$/month

$\mathrm{S}_{\mathrm{e}} \quad$ expected annual saving, US\$/year

$\mathrm{S}_{\mathrm{ub}}$ governmental subsidy rate for the installation, $\%$

\section{Greek symbols}

$\eta=$ panel efficiency, $\%$

$\eta_{\mathrm{M}}=$ module efficiency, $\%$ 


\section{INTRODUCTION}

The fast increase of population in the world and the continuous improvement of the life style, even if in a restricted number of countries, are the causes which have increased, since the beginning of 20th century until now, the energy demand.

Today the energy demand has reached a nonsustainable level with a consequent decrement of the environmental quality and energetic resources of the planet.

Also a notable environmental pollution is growing up, with the energy production. In fact the mechanic and thermal energy used are in great part produced by burning fossil fuels, as the petroleum derivates, coal, and natural gas. From these resources it is produced heat that can be converted in the form of electric or mechanical energy.

In the industrialized countries, petroleum was the most utilized source to produce energy. After the Second World War, with the industrial expansion, petroleum demand duplicated due to the high availability and low cost. Only in end of 70s, after the energetic crisis, it was introduced in the society a new thinking about the way to follow in the energy matter. The problem of limitation of fossil fuel reserves and the attention about the environmental degraded started the use of alternative energy sources (EPE, 2008).

The heat from fossil fuels is derived from the chemical reaction of combustion in which carbon and hydrogen are oxidized. This reaction produces some dangerous substances: carbon monoxide and not burned hydrocarbons, through imperfect and incomplete combustions, sulphur dioxide, sulphuric anhydride and sulphuric acid, for the presence of brimstone in the fuels, and nitrogen oxides, through the oxidation of the atmospheric nitrogen (EPE, 2008).

Another combustion product is carbon dioxide. This is an inert gas present in the atmosphere and it is not dangerous for man. But this gas is not transparent for the infrared radiation emitted by the Earth, so great concentrations of carbon dioxide produce the greenhouse effect and the consequent increase of the temperate of the planet. For this reason, in 1997, the United Nations Framework Convention on Climate Change (UNFCCC) decided a decrease within 2010 of $5 \%$ of climate altering emissions in the world (Kyoto protocol) (EPE, 2008).

The fossil fuels have also the characteristic of being localized in concentred manner: they are situated only in few parts of the planet. This sometimes is the cause of international tensions between countries that posses these sources and countries that want to conquest their control (EPE, 2008).

A small part of energy demand is satisfied by no emitting or low emitting sources. These are the renewable sources of energy, sources which are alternative to petroleum and to the other fossil fuels (EPE, 2008).

Renewable energy is any source of energy that can be used without depleting its reserves. These sources include sunlight or solar energy and other sources such as, wind, wave, biomass and hydro energy. These later sources are indirectly derived from solar energy. Biomass refers to any recently produced organic matter. If the organic matter was produced sustainable then it is considered to be a renewable energy resource (EPE, 2008).

Fossil fuels such as coal, oil and gas come from biomass that was produced in the distant past and has been transformed by geological activity. World reserves of fossil fuels are finite and are being depleted. They are therefore referred to as nonrenewable energy resources (EPE, 2008).

Uranium for the generation of nuclear energy is not a fossil fuel, but still requires the depletion of finite physical reserves so it is included as a nonrenewable energy source. Some geothermal resources may be regarded as renewable because they are derived from energy sources deep within the earth's interior. The energy sources are so large that the rate of depletion by a geothermal energy extraction project is negligible. Projects based on using the remnant heat stored in shallowly placed igneous rocks may be non renewable. However, the use of energy from such sources does not produce greenhouse gases (EPE, 2008).

Another renewable resource, tidal power results from harnessing tidal currents which are caused mainly by the gravitational force of the moon on the oceans as it circles the earth (EPE, 2008).

Biomass is the only renewable energy source that releases carbon dioxide in use. However the carbon dioxide emitted in use is balanced by the incorporation of carbon from the atmosphere into the biomass while the biomass is growing. If the biomass resource is being used sustainable, there are no net carbon emissions over the time frame of a cycle of biomass production. This could be a year for an agricultural crop wastes such as bagasse or decades for forest products. In addition minor amounts of greenhouse gases may be created in producing the technology to transform the renewable energy resource into useable energy (EPE, 2008).

Because the use of renewable energy creates so little greenhouse gas emissions, it is an important part of the world's response to the enhanced greenhouse effect.

The sun provides the energy to heat and light the earth, which makes it habitable. This energy is not traded commercially and hence is not included in energy statistics.

More than $80 \%$ of the world's commercial energy comes from non-renewable fossil fuels (Fig. 1) (EPE, 2008). 


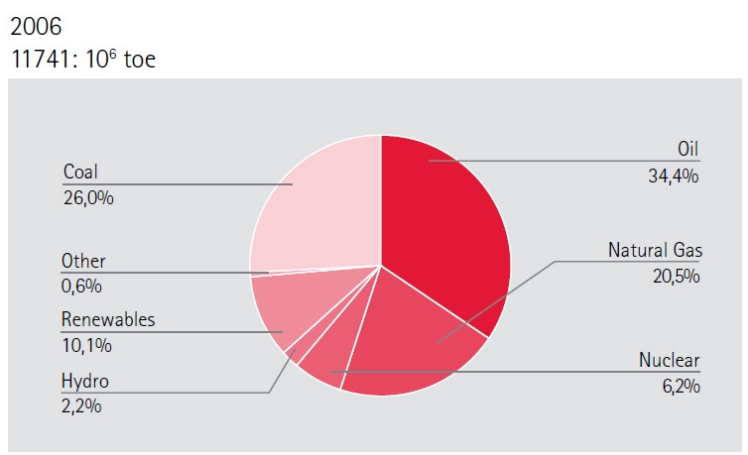

Figure 1. Share of world energy use (2006).

It is evident that to contain the polluting emissions and to avoid climatic alterations is necessary to do a greater use of renewable sources in the production of energy.

There are many technologies to use these sources to produce mechanical energy, heat and electric energy.

Solar energy is used to produce heat and to produce electricity. The photovoltaic (PV) technology allows transforming solar energy in electric energy (NREL, 2009).

In this work is studied a kind of renewable source: the sun, and the technologies to convert the solar radiation energy in electric energy, used in the photovoltaic systems.

The renewable sources of energy are distributed almost evenly in the planet, so, differently than the non renewable sources, they offer the possibility to can produce energy by working with local resources.

Particularly, photovoltaic energy represents an opportunity to produce electricity in the all world places, in particular in the development countries, where there are places where electricity grids are unreliable or non-existent and is inconvenient to make investments in a grid expansion. In remote locations often making photovoltaic power supply the most economic option. In addition, many developing countries have high radiation levels year round (NREL, 2009).

Photovoltaic systems cause few environmental problems. The generating component produces electricity silently and does not emit any harmful gases during operation. The basic photovoltaic material for most common modules made out of silicon is entirely benign, and is available in abundance (NREL, 2009).

One criticism of early PV modules was that they consumed more energy during their production than they generated during their lifetime. With modern production methods and improved operational efficiencies this allegation is no longer true. The exact energy payback is obviously dependent on the available solar resource and on the degree to which the system is operational. High levels of solar irradiation and a high utilization factor will offer more rapid energy paybacks than if there is less sun and less usage, but typically energy payback will be realized within three to four years (NREL, 2009).

Besides, in the economic remarks relative to the using of energetic sources, the caused environmental damages are not considered. If that was done, the energy produced by photovoltaic, and also the energy produced by others renewable sources, would conquest more competitiveness in confrontation with the traditional non renewable sources (NREL, 2009).

In example, applications in which photovoltaic technologies can be used are related:

- Agriculture:

o water pumping, irrigation;

o electric fencing for livestock and range management;

- Community:

o water pumping, desalination and purification systems;

o lighting for schools and other community buildings;

- Domestic

o lighting, enabling studying, reading, income-producing activities and general increase in living standards;

o $\mathrm{TV}$, radio, and other small appliances;

o water pumping;

- Healthcare:

o lighting forwards, operating theatre and staff quarters;

o medical equipment;

$\circ$ refrigeration for vaccines;

o communications (telephone, radio communications systems);

o water pumping;

o security lighting;

- Small enterprises:

o lighting systems, to extend business hours and increase productivity;

$\circ$ power for small equipment, such as sewing machines, freezers, grain grinders, battery charging;

$\circ$ lighting and radio in restaurants, stores and other facilities.

Photovoltaic systems create no emission in the electricity production. Avoided emissions are a very positive aspect. In a study realised by Kroposki and De Blasio (2000) is resulted that a $10 \mathrm{~kW}$ photovoltaic system in Colorado avoids $10,105 \mathrm{~kg}$ in $\mathrm{CO}_{2}$ emissions and $1,801 \mathrm{~kg}$ in $\mathrm{NO}_{\mathrm{x}}$ emissions.

No pollution of the photovoltaic systems can be inserted in the economic analysis. The Denver Service Guideline estimated the costs associated with the production of carbon dioxide $\left(\mathrm{CO}_{2}\right)$ in $0.0088 \mathrm{US} \$ / \mathrm{kg}$, of sulphur dioxide $\left(\mathrm{SO}_{2}\right)$ in $1.65 \mathrm{US} \$ \mathrm{~kg}$, and of nitrogen oxides $\left(\mathrm{NO}_{\mathrm{x}}\right)$ in 7.48 US\$/kg (Effert and Thompson, 2000).

The mean installation costs (including the devices) of photovoltaic systems were 5.7US $\$ / \mathrm{W}_{\mathrm{p}}$ for grid connected systems and $13.9 \mathrm{US} \$ / \mathrm{W}_{\mathrm{p}}$ for 
standalone system in USA (Mortensen, 2001). These high costs make high also the cost of the electricity produced by the photovoltaic plant.

The panels' costs influence much the final installation cost, from $40 \%$ to $75 \%$ (Delahoy and Kiss, 2000). The photovoltaic energetic source will be very alternative when the panels cost will be decreased, as is the perspective.

Hybrid options based on sustainable resources, mainly photovoltaic, have been studied as solution for small rural villages' energy demand, such as (Chendo and Salawu, 1989; Dhere, 1989; Bailey et al., 1991; Song, 1994; Leitch and Van Der Linde, 1995; De Groot, 1997; Harford, 1998; Valente and Almeida, 1998).

Aspects about the sun, such as solar radiation, solar position, evaluation of extraterrestrial solar radiation, and evaluation of terrestrial solar radiation (including measuring of solar radiation and estimation of the solar radiation) theory, assumptions, and equations had been studied from (Kreith and Kreider, 1976; Kreider and Kreith, 1977; Kraemer, 1980; Barra, 1981; Kreider, 1981; Kreider and Kreith, 1981).

Photovoltaic cells had been studied through their features, such as operating principle, types of photovoltaic cells, their current versus voltage curves, photovoltaic systems behaviour (photovoltaic grid connected system - PVGC and photovoltaic standalone system - PVSA), photovoltaic components (generator, including connection of more than one photovoltaic module, parameters of a photovoltaic generator, $\mathrm{I} \times \mathrm{V}$ curve of a photovoltaic generator; inverter; battery; charge controller; main fusebox; and meters), also theory, assumptions, and equations (Ruther, 1998; GTES, 1999; Effert, and Thompson, 2000; Erge et al., 2001; ENEA, 2002a; ENEA, 2002b).

\section{METHODOLOGY}

The study presents the software SOLAR 1.1 developed with purpose of helping the choice of photovoltaic panels available commercially including electric needs calculation for the installation. This new version of program help also to conduce the economic analysis for grid connected or standalone photovoltaic systems for the choice of convenient values of investment rate and annuity factor and it calculates the payback period of investment in the photovoltaic plant.

\section{ECONOMIC ANALYSIS OF PHOTOVOLTAIC SYSTEMS}

The economic analysis of a photovoltaic plant depends on the kind of system. In grid connected system, the economic feasibility is based on the condition that the cost of production of electricity compensates the supplementary costs in relation at the conventional supply system (by utility). In a photovoltaic system applied in a rural community (stand alone system), the expected annual saving is based on the condition that the cost of electricity production compensates the costs relative at the expansion of the electric grid (marginal cost).

In this chapter is treated a methodology for the study of the economic feasibility. This methodology was developed by the theory of Silveira (1994) and Silveira et al. (1995) with some adjunctive considerations.

\section{Calculation of Electric Energy Production Cost}

The calculation of the electric energy production cost in the photovoltaic system considers the investments needed for buying, installation, operations and maintenance of the system, such as Eq. (1).

$C_{e l}=\frac{I_{p l} \times\left(1-\frac{S_{u b}}{100}\right)}{E_{p}} \times f+C_{o p}+C_{m a}$

The annuity factor is calculated through Eqs. (2) and (3).

$$
\begin{aligned}
& f=\frac{q^{k} \times(q-1)}{q^{k}-1} \\
& q=1+\frac{r}{100}
\end{aligned}
$$

The produced energy during a year $E_{p}$ is an estimation of the quantity of the electricity that the photovoltaic system can produce in a year with the solar radiation characteristic of the place where the system is planted, and with some panels characteristics as efficiency and surface. Eq. (4).

The produced energy can be esteem through the

$$
E_{p}=\frac{\eta_{M}}{100} \times R_{A} \times A
$$

The total investment cost $\mathrm{I}_{\mathrm{pl}}$ can be calculated through Eq. (5).

$$
I_{p l}=C_{m} \times n_{m}+C_{d}+C_{b}
$$

The peripheral components are the devices in the system different from photovoltaic generator, there are inverter, meters, main fuse box in a grid connected system or inverter and charge controller in a standalone system. 
This cost is majority composed by the inverter cost and, with good approximation; it can be taken equal to the $20 \%$ of the modules costs.

The cost of battery is null in case of grid connected system and can be taken equal to $20 \%$ of modules cost in case of standalone systems (Valente and Almeida, 1998). (6).

The operation costs Cop can be taken in the Eq.

$$
C_{o p}=\frac{n_{t e c} \times S_{a l} \times n_{w}}{E_{p}}
$$

As a convention, the number of technicians needed for the operation can be considered:

$-\mathrm{n}_{\mathrm{tec}}=0$ if $\mathrm{P} \leq 2 \mathrm{~kW}$;

- $\quad \mathrm{n}_{\mathrm{tec}}=1$ if $\mathrm{P}>2 \mathrm{~kW}$ in standalone systems;

- $\mathrm{n}_{\text {tec }}=1$ if $2<\mathrm{P} \leq 4 \mathrm{~kW}$ in grid connected systems;

$-\mathrm{n}_{\mathrm{tec}}=2$ if $\mathrm{P}>4 \mathrm{~kW}$ in grid connected systems.

There is to observe that in a standalone system (isolated system), it can generally trained a person of the community as technician.

The maintenance cost $\mathrm{C}_{\mathrm{ma}}$ can be taken equal to $10 \%$ of the total investment cost $\mathrm{I}_{\mathrm{pl}}$, divided for the value of energy produced in a year $\mathrm{E}_{\mathrm{p}}$.

\section{Calculation of Expected Annual Saving}

The annual saving derived by the implantation of a photovoltaic generation system is determined by the annual gains due at the electricity production. The benefit is also a function of the produced electricity.

In a grid connected system the expected annual saving is calculated through Eq. (7).

$$
S_{e}=E_{p} \times\left(P_{e l}-C_{e l}\right)
$$

$\mathrm{P}_{\mathrm{el}}$ is the price at which the electricity would be bought from the grid concessionary if the photovoltaic system was not installed.

The value of $P_{\text {el }}$ is different for each country and in the same country is different for the different quantity of electric energy time drain in a time interval, and for the different activities: residential, commercial and industrial sector.

In the Table 1 are shown the mean values of electric tariff for some countries, for residential uses.

Table 1. Mean electric tariff in European countries in residential uses.

\begin{tabular}{|c|c|}
\hline Germany & 0.16 \\
\hline Greece & 0.09 \\
\hline Hungary & 0.08 \\
\hline Ireland & 0.12 \\
\hline Italy & 0.18 \\
\hline Luxemburg & 0.13 \\
\hline Netherlands & 0.20 \\
\hline Portugal & 0.13 \\
\hline Spain & 0.13 \\
\hline Sweden & 0.09 \\
\hline Switzerland & 0.16 \\
\hline UK & 0.13 \\
\hline
\end{tabular}

\begin{tabular}{ll}
\hline Country & Electric price in US\$/kWh \\
\hline Austria & 0.16 \\
Belgium & 0.15 \\
Czech Republic & 0.09 \\
Denmark & 0.20 \\
France & 0.16
\end{tabular}

In case of standalone system the comparison of the cost $\mathrm{C}_{\mathrm{el}}$ with the price $\mathrm{P}_{\mathrm{el}}$ is not the right way to calculate the expected annual saving. In this case there is not grid connection and so in the analysis of annual saving the cost of the eventual connection with the grid must be considered, such as Eq. (8).

$S_{e}=E_{p} \times\left(C_{m_{e x}}-C_{e l}\right)$

In both situations, the value of the expected annual saving is influenced by the value of the governmental subsidy rate through the value of the electricity production $\operatorname{cost} \mathrm{C}_{\mathrm{el}}$.

Only the cases in which the expected annual saving results positive, indicate a convenience in planting the photovoltaic system.

The value of amortisation period for which the annual saving is null, is the payback period. Payback period represents the minimum number of years needed to have the return of the investment.

\section{Examples of Economic Analysis for PV System}

In this paragraph, there are shown some values of the electricity production cost $\mathrm{C}_{\mathrm{el}}$ and of the expected annual saving $\mathrm{Se}$ in different type of photovoltaic system and for variable values of the interest rate $r$, amortisation period $\mathrm{k}$ and governmental subsidy rate.

Figure 2 shows the electricity production cost $\mathrm{C}_{\mathrm{el}}$ for different value of subsidy and interest rate for a standalone and a grid connected system, when the amortisation period is 10 years and considering a mean modules cost of $4 \mathrm{US} \$ / \mathrm{W}_{\mathrm{p}}$. 


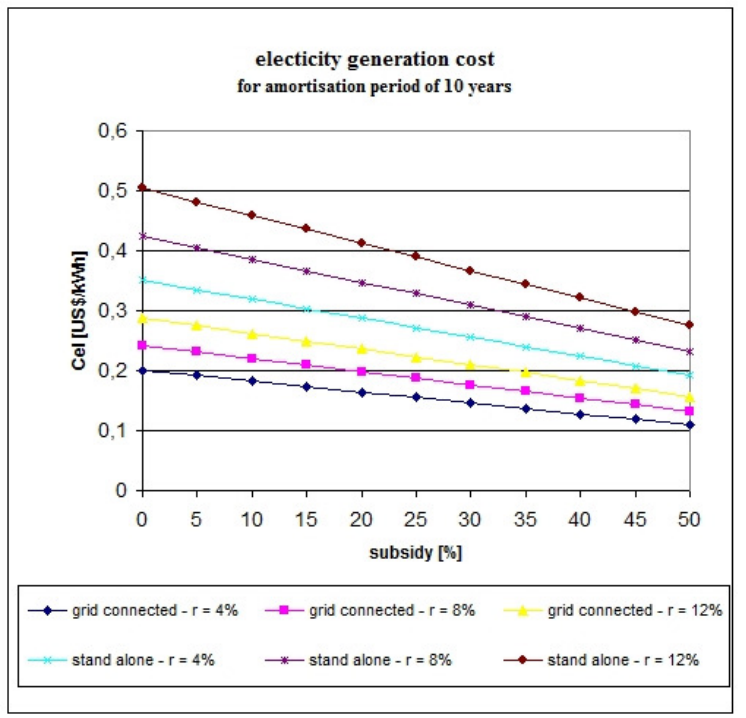

Figure 2. Electricity generation cost.

In the Fig. 3 is shown the annual saving variations for different values of the electric tariff, when the modules cost is $4 \mathrm{US} \$ / \mathrm{W}_{\mathrm{p}}$, the amortisation period is 10 years and the interest rate is $4 \%$. This annual saving is calculated for a grid connected photovoltaic system with an installed power of $10 \mathrm{~kW}$. In this figure it can see positive values of annual saving only when:

- subsidy equal to $0 \%$ and electric tariff is higher than $0.2 \mathrm{US} \$ / \mathrm{kWh}$;

- subsidy equal to $5 \%$ and electric tariff is higher than $0.19 \mathrm{US} \$ \mathrm{kWh}$;

- subsidy equal to $10 \%$ and electric tariff is higher than $0.18 \mathrm{US} \$ / \mathrm{kWh}$;

- subsidy equal to $20 \%$ and electric tariff is higher than $0.17 \mathrm{US} \$ / \mathrm{kWh}$;

- subsidy equal to $30 \%$ and electric tariff is higher than $0.15 \mathrm{US} \$ / \mathrm{kWh}$;

- subsidy equal to $40 \%$ and electric tariff is higher than $0.13 \mathrm{US} \$ / \mathrm{kWh}$;

- $\quad$ subsidy equal to $50 \%$ and electric tariff is higher than $0.11 \mathrm{US} \$ / \mathrm{kWh}$.

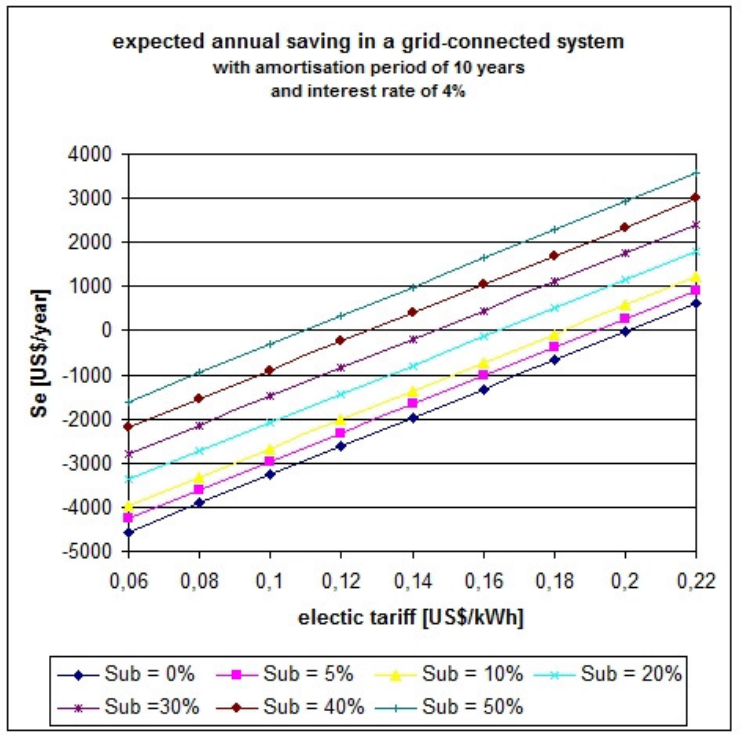

Figure 3. Expected annual saving in a grid connected PV system of $10 \mathrm{~kW}$.

In the Fig. 4 is shown the annual saving variations for a standalone system for different values of the marginal cost of grid expansion. The expected annual saving is calculated with the same values of the previous case: installed power of $10 \mathrm{~kW}$, modules cost is $4 \mathrm{US} \$ / \mathrm{W}_{\mathrm{p}}$, amortisation period is 10 years and interest is $4 \%$. In this case we can see a positive value of annual saving for:

- subsidy equal to $5 \%$ and marginal cost higher than 0.34US\$/kWh;

- subsidy equal to $10 \%$ and marginal cost higher than $0.32 \mathrm{US} \$ / \mathrm{kWh}$;

- subsidy equal to $20 \%$ and marginal cost higher than 0.29US $\$ / \mathrm{kWh}$;

- subsidy equal to $30 \%$ and marginal cost higher than $0.26 \mathrm{US} \$ / \mathrm{kWh}$;

- subsidy equal to $40 \%$ and marginal cost higher than $0.23 \mathrm{US} \$ / \mathrm{kWh}$;

- $\quad$ subsidy equal to $50 \%$ and electric tariff is higher than 0.19US\$/kWh. 


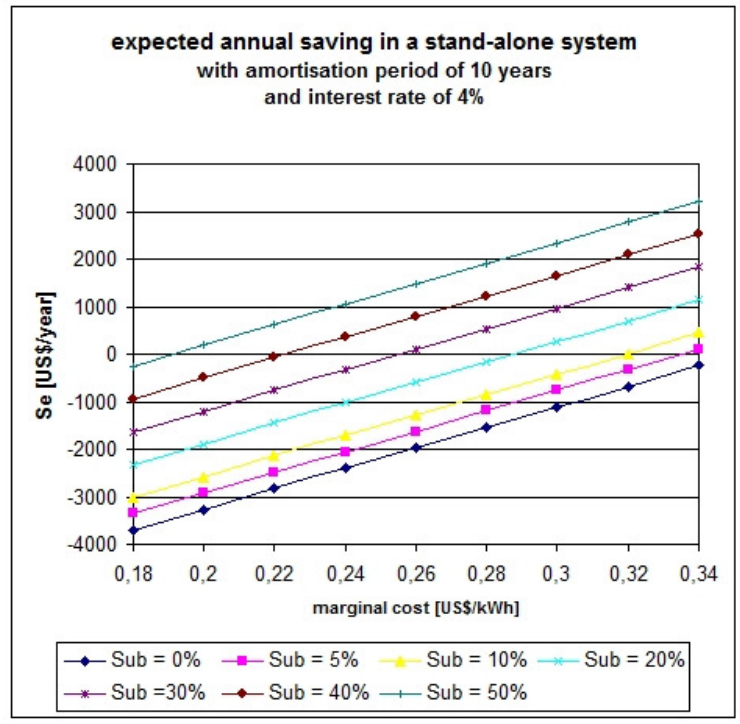

Figure 4. Expected annual saving in a stand alone PV system of $10 \mathrm{~kW}$.

Figures 5 and 6 show the variation of the annual saving value in the two photovoltaic system types, for variable values of the amortisation period. In these diagrams the following values of parameters are considered for making the economic analysis:

- installed power: $10 \mathrm{~kW}$;

- interest rate: $4 \%$;

- governmental subsidy rate: $0 \%, 25 \%$, and $50 \%$;

- electric tariff: $0.09 \mathrm{US} \$ \mathrm{kWh}$ (for the grid connected system);

- marginal cost: $0.20 \mathrm{US} \$ / \mathrm{kWh}$ (for the stand alone system).

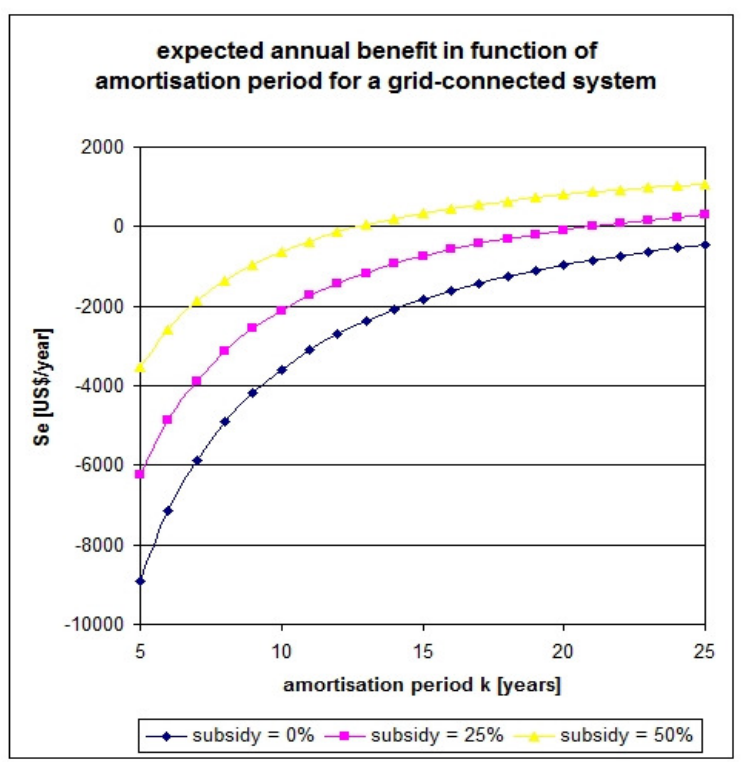

Figure 5. Expected annual saving in function of amortisation period in a grid connected system.

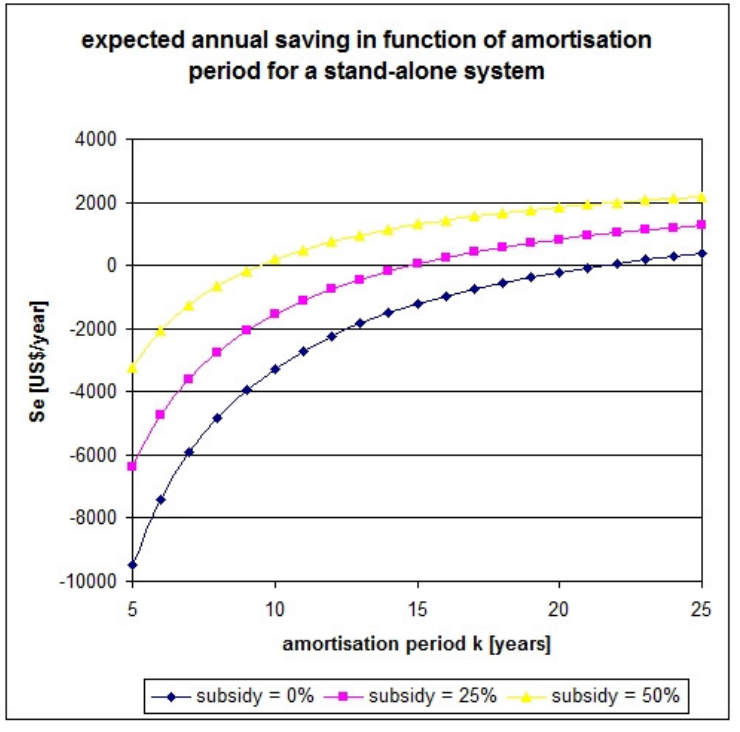

Figure 6. Expected annual saving in function of amortisation period in a standalone system.

In the Fig. 5, it can see a positive annual saving for am amortisation period major of 13 years when the subsidy is $50 \%$ and for an amortisation period major of 21 years when the subsidy is $25 \%$. With a subsidy of $0 \%$ the expected annual saving is always negative.

The value of the amortisation period that gives a null value of annual saving is the payback period. That is the minimum time it takes to recover the investment costs.

In the case of the stand alone system, shown in the Fig. 6, it can see a positive annual saving for an amortisation period major of 12 years when the subsidy is $50 \%$ and for an amortisation period major of 19 years when the subsidy is $25 \%$. Also in this case, with a subsidy of $0 \%$ the benefit is always negative during 25 years.

As it was told before, the economic convenience in the feasibility of a photovoltaic system can be evaluated on the value of the expected annual saving: when it assumes negative values there is no convenience in the investment.

These diagrams do know how the governmental subsidy rate is important for the economic feasibility of a photovoltaic plant and how it is a parameter that can do become economically competitive the photovoltaic technologies.

\section{SOLAR 1.1}

SOLAR 1.1 is software that calculates the mean insolation of a place helps to choose the type of modules for a photovoltaic plant and executes the calculations to conduce the economic analysis of the photovoltaic system. 
Main

When the software SOLAR 1.1 is run, it starts with the window showed in the Fig. 7. In this window is possible to choose the language among Portuguese, Italian, and English. The language choice is a new function that was not present in the first version SOLAR 1.0, developed only in Portuguese.

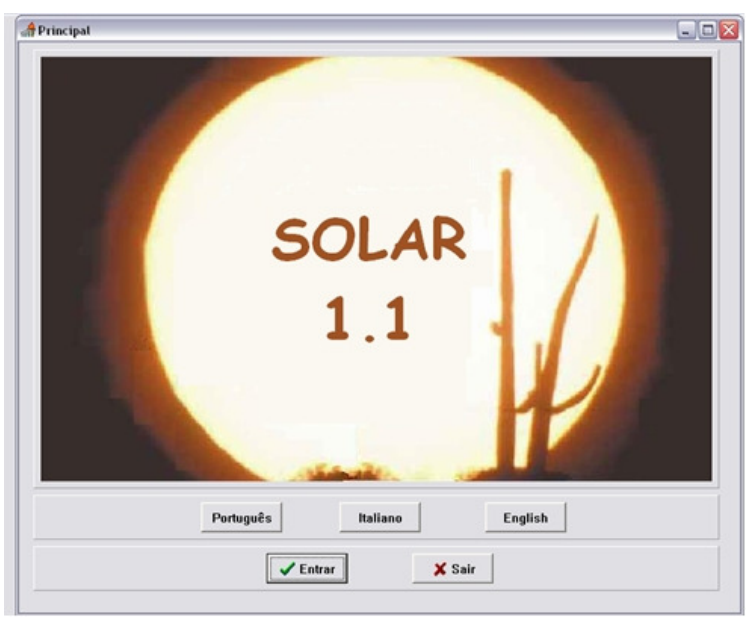

Figure 7. Open window of SOLAR 1.1.

\section{Estimate of the Place Insolation}

The window called "Estimate of the Place Insolation" is the first calculation block of the software. In this form the calculation of the annual mean insolation is made.

This is a new function of the software SOLAR. This calculation of the annual mean isolation was not included in the previous version in which the value of insolation was an input datum, the knowledge of which was needed before using the software. Fig. 8 shows this form.

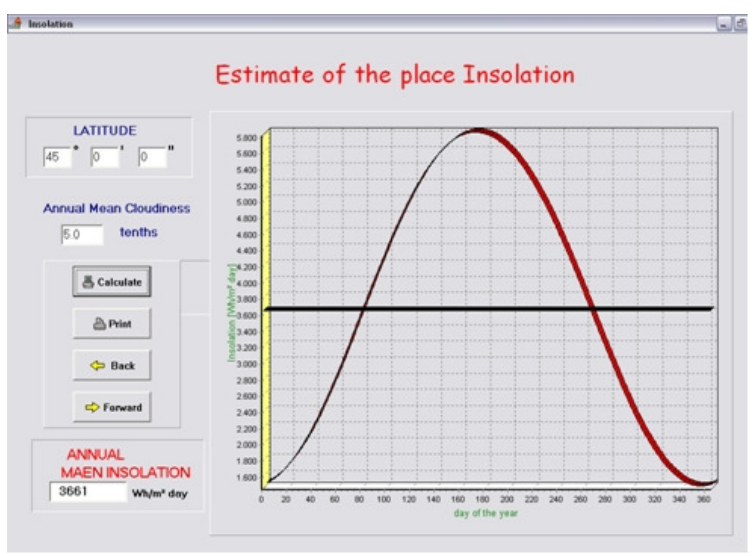

Figure 8. Estimate of the place insolation.

The data needed to operate the calculation are: latitude of the place, in degree; and annual mean cloudiness, in tenths of overcast sky (this value can be taken from meteorological tables).

After introducing these data, clicking the button Calculate, the software can esteem the values of the insolation for each day of the year. The trend of the esteemed insolation in a year is shown in the curve that is in the form. In this curve is also marked the annual mean value of the insolation and this value is wrote in the cell annual mean insolation. This is the value that will be used in the following calculations.

In the form there are some other buttons that consent to operate the print of the form (button Print) or to return at the previous window (button Back).

\section{Installed Power}

The successive window is the second calculation block of this software (Fig. 9). Here there is the introduction of the needed power and the calculation of the peak power of the photovoltaic plant. Through this window is also possible to access at the data base block in which the panels archive can be manipulated.

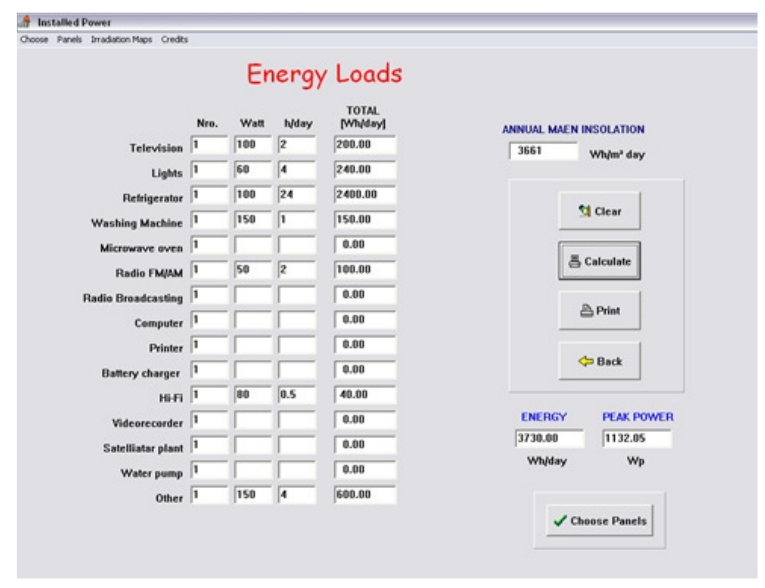

Figure 9. Calculation of installed power.

In this window, calculations previous of the panels choice are done.

The input data necessary for calculating are: number of each load; power of each load; and mean daily number of hours of functioning for each load.

After having introduced these values, clicking the button Calculation, the software calculates the values of the daily demand energy and the peak power and shows these values in the cells called "Energy and Peak Power".

If the peak power value needed in the photovoltaic plant is known, it is possible to insert directly it, without necessity of imputing the data for calculation. Eq. (9).

The daily demand energy is calculated through 


$$
E=\sum_{i=1}^{k} n_{i} \times P_{i} \times H_{i}
$$

Knowing the value of the energy E, the software can calculate the nominal plat power (peak power) through the Eq. (10).

$P_{p}=\frac{E \times 1,000}{0.9 \times R}$

In Eq. (10), "1,000" is a standard value of irradiance, in $\mathrm{W} / \mathrm{m}^{2}$.

The value of the annual mean insolation $\mathrm{R}$ is the same calculated in the previous window, it is also shown in this form in the cell annual mean insolation.

After the calculation of the peak power $\mathrm{Pp}$, clicking the button Choose Panels, it will be opened another window in which there is the next calculation block that operates the panels choice. In this window there is a menu with the following items: Choose, it is an alternative way to the button Choose Panels; Panel, it opens the window Data Base that permits to view and modify the archive; Irradiation Maps; Credits, it is a window that shows authors of the software SOLAR 1.1 (Fig. 10).

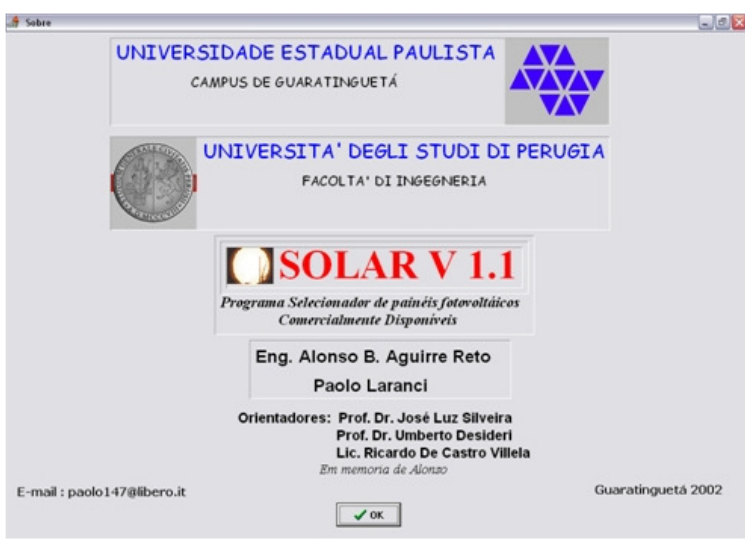

Figure 10. Credits.

In this window are others buttons: Clear, it cleans the cells; Print, it prints the window; Back, it closes the window and reactive the precedent window.

\section{Data Base}

This window is accessible through the menu of the window Installed Power. It shows the data contained in the software archive. The archive has 251 types of photovoltaic modules made by 34 producers. The Table 2 contains the list of manufacturers of the photovoltaic panels inserted in the software archive.
Table 3. Panels producer in the SOLAR archive.

PRODUCER COUNTRY INTERNET SITE

\begin{tabular}{llll}
\hline 1 & Alwitra & Germany & \\
2 & ASE & Germany & www.ase-internationa.com \\
3 & Astropower & USA & www.astropower.com \\
4 & Atersa & Spain & www.atersa.com \\
5 & Bp Solarex & India & www.bpsolar.com \\
& & USA & www.bpsolar.com \\
& & Spain & www.bpsolar.com \\
6 & Creaton & Germany & www.creaton.com \\
7 & Dunasolar & Hungary & www.dunasolar.com \\
8 & Eurosolare & Italy & www.eurosolare.it \\
9 & Fortum & Finland & www.fortum.com \\
10 & GPV & Sweden & www.eat.de \\
11 & Helios & Italy & www.heliostechnology.com \\
12 & IBC & USA & www.ibc-solar.de \\
13 & Isofoton & Spain & www.isofoton.es \\
14 & Kyocera & Japan & www.kyocera.de \\
15 & Pfeiderer & Germany & www.pfeiderer-dach.de \\
16 & Phönix & Spain & www.sonenstronag.de \\
17 & Photowatt & France & www.photowatt.com \\
18 & Pilkinton & Germany & www.pilkinton.com \\
19 & Rathscheck & Germany & www.rathscheck.com \\
20 & Schüco & Germany & www.schueco.de \\
21 & Schell Solar & Holland & \\
22 & Siemens & USA & www.siemenssolar.com \\
& Solar & USA/Brazil & www.siemenssolar.com \\
23 & Solar Fabrik & Germany & www.solar-fabrik.de \\
24 & Solar World & Sweden & www.solarworld.de \\
25 & Solarnova & Germany & www.solarnova.de \\
26 & Solarwatt & Garmany & www.solarnova.com \\
27 & Solawerk & Germany & www.solarwerk.com \\
28 & Solon & Germany & www.solonag.com \\
29 & Sunware & Germany & www.sunware.com \\
30 & Thyssen & Germany & www.thyssen-solartec.de \\
31 & Heisterholz & Germany & www.heisterholz.de \\
32 & United Solar & USA & www.ovonic.com/unisolar.html \\
33 & Webasto & Germany & www.mastervolt.com \\
34 & Würth Solar & Germany & www.wuerth-elektronik.de \\
\hline & & &
\end{tabular}

In the window Data Base the characteristics of each module are shown and it is possible to modify the archive adding new items or changing the existent items, so, for example, it is possible to update the value of prices of the panels. Figure 11 shows the window Data Base. 


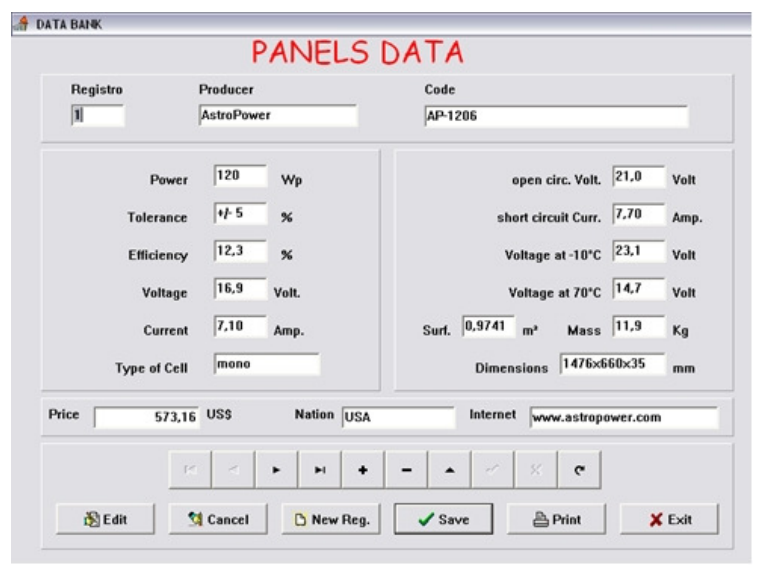

Figure 11. Data base window.

The modules characteristics contained in the archive are: Producer; Code; Power; Tolerance; Efficiency; Voltage; Current; Type of cell; Open circuit voltage; Short circuit current; Voltage at $10^{\circ} \mathrm{C}$; Voltage at $70^{\circ} \mathrm{C}$; Surface; Mass; Dimensions; Price; Country; Internet site.

\section{Panels Choice}

In this window the software SOLAR operates the choice of photovoltaic panels among the commercial available types inserted in the archive. Figure 12 shows an example of choice.

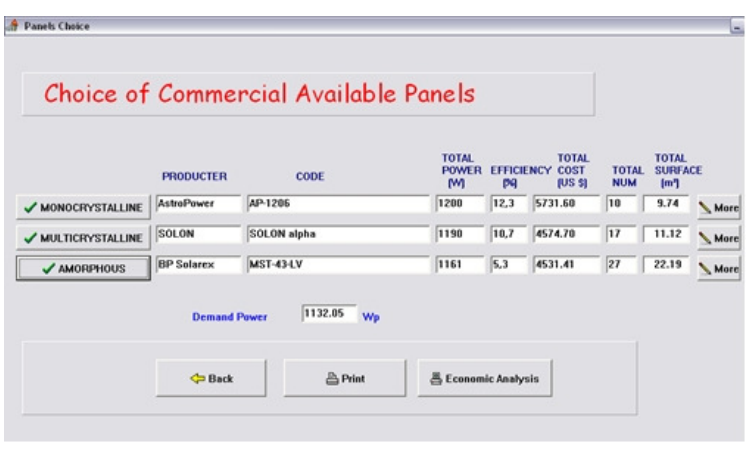

Figure 12. Panels choice window.

There are three output panels types in the choice: one for each type of cell. So there will be a monocrystalline, a multicrystalline, and an amorphous panel type.

In the window some information on the panels are shown: Producer; Code; Total power; Efficiency; Total cost; Number of panels needed in the photovoltaic plant; Total surface.

To show the others panels characteristics is needed to click on the button More, situated after the writing relative to the panel.

The choice of panels is made through the valuation of the ratio cost/produced energy in a year.
The produced energy in a year is calculated by the Eq. (11).

$$
E_{P}=R_{A} \times A \times \frac{\eta}{100}
$$

So the choice is in function of three panel characteristics: Cost; Efficiency; Surface.

The value of the annual insolation RA is calculated as the integral of the curve of the daily insolation shown in the window Annual Mean Insolation, evaluated through Eq. (12).

$$
R_{A}=\int_{0}^{365} R d t
$$

In the archive there are some items of panel without the value of their cost. For these panels the software estimates the cost through equations that were deduced from the values of others panels with similar characteristics. The panels characteristic taken to deduce the estimated value of the cost, is its peak power. To find these equations the panels data were separated in group for each type: monocrystalline, multicrystalline, and amorphous.

Figures 13 to 15 are shown the trend of the cost with the power for the three types.

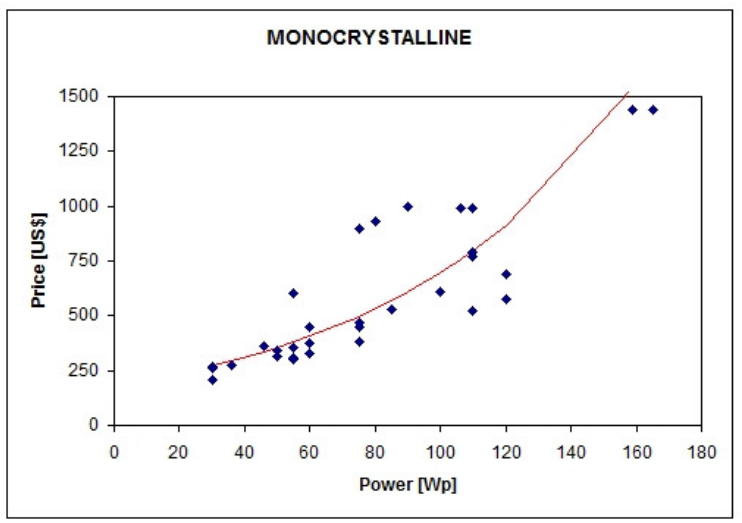

Figure 13. Cost of monocrystalline panels vs. maximum power. 


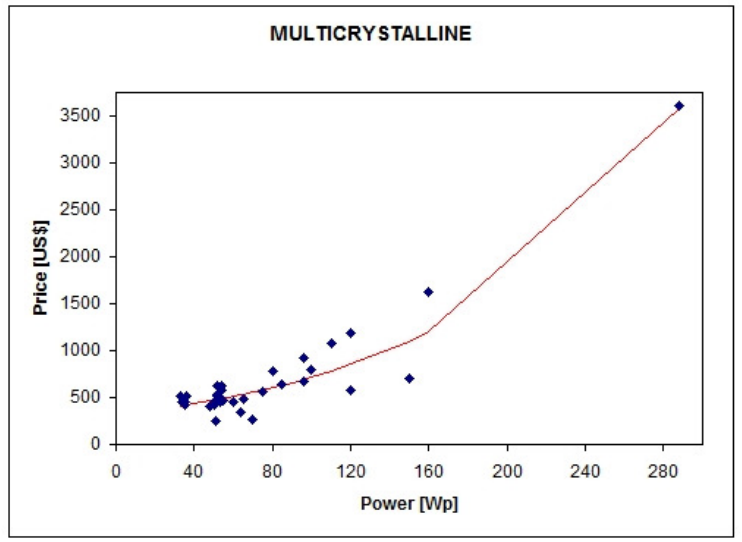

Figure 14. Cost of multicrystalline panels vs. maximum power.

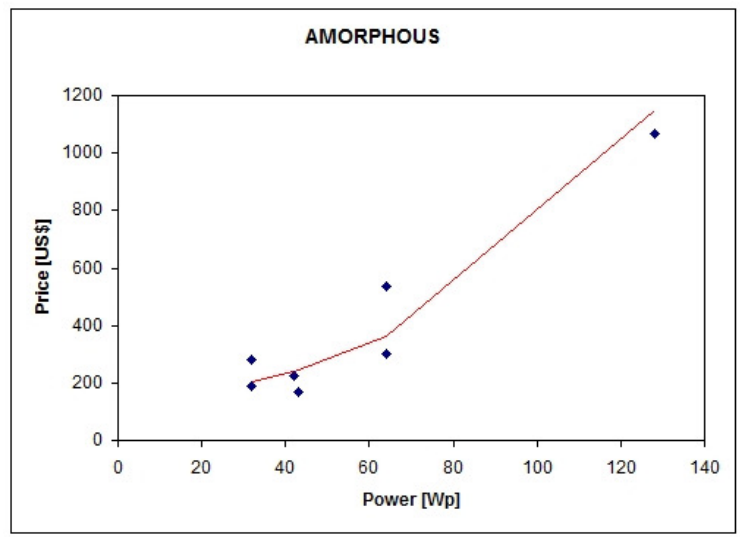

Figure 15. Cost of amorphous panels vs. maximum power.

Through these diagrams (Figs. 13-15), the equations to estimate the cost of panel was deduced in function of the nominal power, such as Eq. (13) for monocrystalline panels, Eq. (14) for multicrystalline panels, and Eq. (15) for amorphous panels.

$C_{m}=182.322875 \times 1.013406^{P_{p}}$

$C_{m}=306.118327 \times 1.008568^{P_{p}}$

$\log \left(C_{m}\right)=0.0180791 \times P_{p}+4.73025$

After the choice of panel, the economic analysis can be started, clicking the button Economic Analysis.

In the window there are also a Print button, to print the result, and a Back button, to return at the precedent window.

\section{Economic Analysis - Setting}

The calculation block to operate the Economic Analysis on a photovoltaic system is a new function inserted in the version 1.1 of SOLAR. So this version software becomes an instrument that can help for studying the economic feasibility of the photovoltaic implantation.

The first window of the Economic Analysis is shown in the Fig. 16. It is the window in which it happens the input the information needed for the economic analysis.

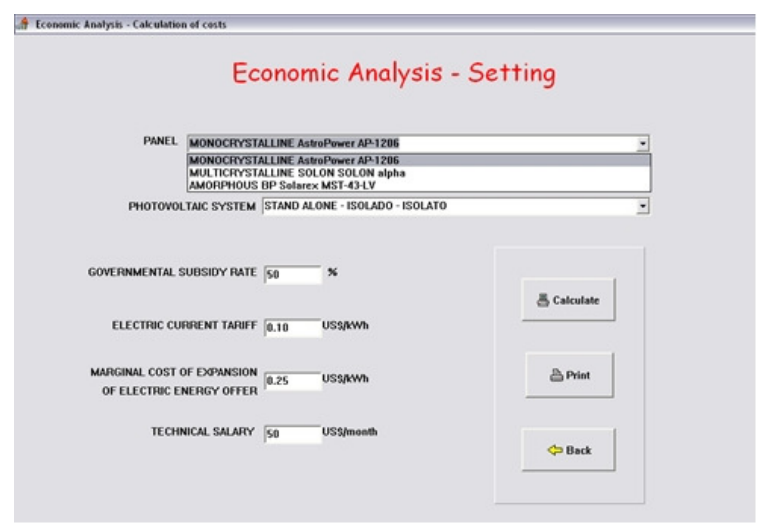

Figure 16. Economic analysis - setting.

The information needed for the analysis that can be inserted in this windows are: Panel type, it can be chosen among the three type resulted in the precedent window; System type, it can be chosen between grid connected or stand alone system; Governmental subsidy rate in \%; Electric current tariff in US $\$ / \mathrm{kWh}$; Marginal cost electricity tariff of expansion of electric energy offer in US\$/kWh; Technical salary in US\$/month.

After having inserted these data, clicking the Calculate button, the calculations will be operated and the results will be shown in the following window.

Also here it is possible to print, through the Print button and to go back at the precedent window, through the Back button.

\section{Economic Analysis - Calculation of Costs}

In this window the results of calculated costs in the photovoltaic system are shown (Fig. 17). 


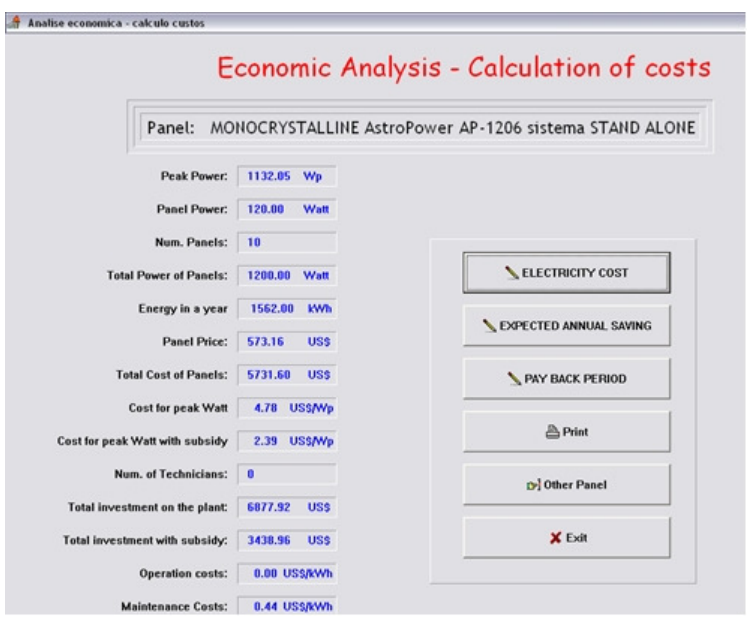

Figure 17. Economic analysis - calculation of costs.

The calculated costs are all that are necessary to conduce the economic analysis. Through the values shown in this window, it is possible to obtain the cost of electricity produced in the photovoltaic system and the expected annual saving of the investment for the installation.

In this window the following information are shown: panel and photovoltaic system type; peak power [Wp]; power of each panel [Wp]; numbers of panel needed in the photovoltaic system; power of all panels [Wp]; produced power in a year [Ep]; price of a panel [US\$]; price of all panels [US\$]; number of technical needed for the system operation; installation cost for peak Watt; installation cost for peak Watt with governmental subsidy rate; total investment cost for the implantation [US\$]; total investment cost for the implantation with public subsidy [US\$]; value of operation cost [US\$/kWh]; value of maintenance cost [US $\$ / \mathrm{kWh}$.

On the right of the window there are the buttons of command that can be start in this window: Exit, it closed the software; Other panel, it permit to go back and to change the analysis data; Print, it prints the results of calculations; Electricity cost (Fig. 18), it opens a window in which is shown the diagram with the trend of the electricity cost in the photovoltaic system for different values of the amortisation period and for different values of the investment rate. It is possible to change the value of the governmental subsidy rate and to draw new curves clicking the button New Draw; Expected Annual Saving (Fig. 19), it opens a window in which is shown the diagram with the trend of the expected annual saving in the photovoltaic system for different values of the amortisation period and for different values of the investment rate. It is possible to change the value of the governmental subsidy rate and to draw new curves clicking the button New Draw; Payback Period (Fig. 20), it opens a windows in which is calculated the payback period, of the photovoltaic system in analysis, for the chosen value of the interest rate and the governmental subsidy rate.

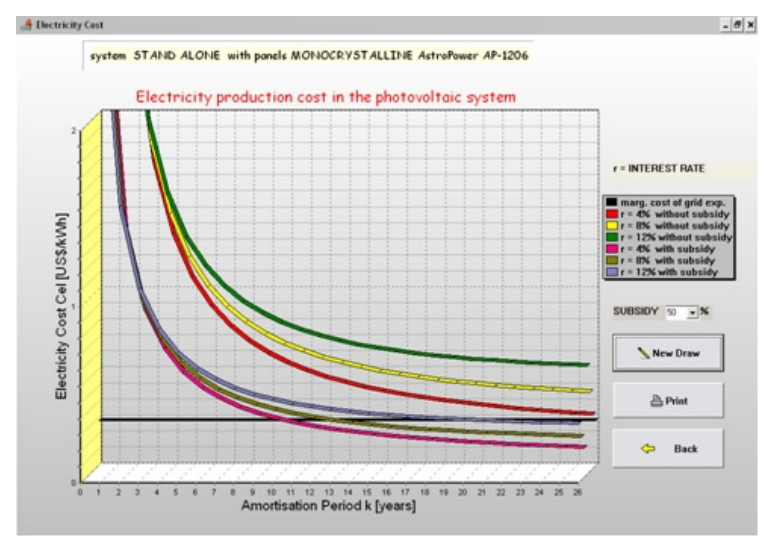

Figure 18. Electricity production cost in the photovoltaic system.

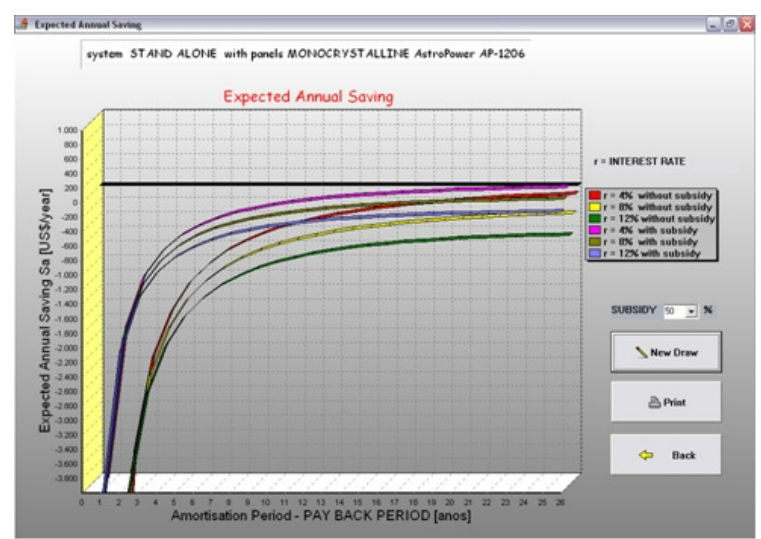

Figure 19. Expected annual saving.

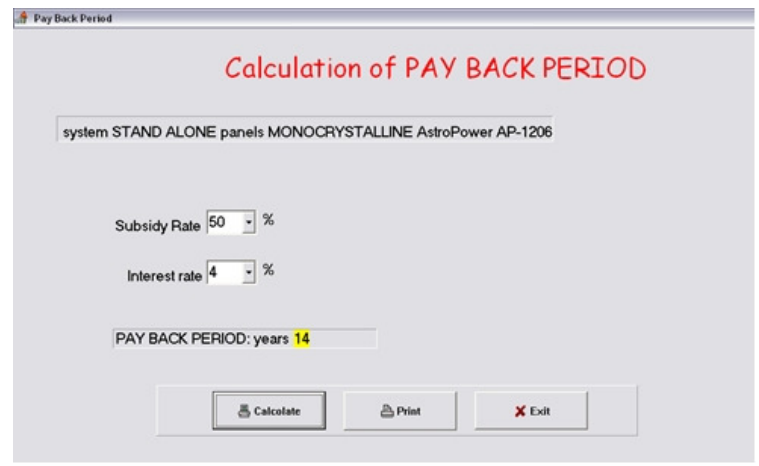

Figure 20. Payback period.

Through these last three windows it is possible to evaluate the convenience in the implantation of the photovoltaic system.

Also, they can be offer an useful help in the choice of the convenient value of the interest rate and the amortisation period in the investment for the photovoltaic installation. 


\section{CONCLUSIONS}

The photovoltaic systems can be a good alternative source to satisfy energetic problem for the low environmental impact deriving by their utilisation. But they result not completely competitive in the economic confrontations with others energy sources for their high costs of implantation.

The benefits and the observations about using of photovoltaic are reassumed in the following:

- Energetic:

$\circ$ the stand alone PV systems offer the possibility to have electric energy in remote place where the electric grid is inexistent and then there is no convenience to install it;

○ the grid connected PV systems can be located at both residential and commercial locations, they can be used to reduce peak demand when its output is properly matched with load usage;

- Environmental:

$\circ$ photovoltaic energy is a clean renewable resource. The fuel supply for these systems although variable is also free and unending;

o photovoltaic systems create no emission in the electricity production. Avoided emissions is a very positive aspect. In a study realised by Kroposki and De Blasio (2000) is resulted that a $10 \mathrm{~kW} \mathrm{PV}$ system in Colorado avoids $10,105 \mathrm{~kg}$ in $\mathrm{CO}_{2}$ emissions and $1,801 \mathrm{~kg}$ in $\mathrm{NO}_{\mathrm{x}}$ emissions.

- Economic:

$\circ$ the mean installation costs (including the devices) of photovoltaic systems in 2000, were 5.7US $\$ / \mathrm{W}_{\mathrm{p}}$ for grid connected systems and 13.9US $\$ / \mathrm{W}_{\mathrm{p}}$ for standalone system in USA (Mortensen, 2001). These high costs make high also the cost of the electricity produced by the photovoltaic plant;

$\circ$ the panels costs influence much the final installation cost, from $40 \%$ to $75 \%$ (Delahoy and Kiss, 2000). The PV energetic source will be very alternative when the panels cost will be decreased, as is the perspective;

$\circ$ in the case studied in this work was seen as in situation in which the electric tariff is low, as in the Brazilian condition (electricity price is $0.08 \mathrm{US} \$ / \mathrm{kWh}$ ), the $\mathrm{PV}$ energy can be competitive only if the government incentives the installation with subsidy;

o no pollution of the PV systems can be inserted in the economic analysis. The Denver Service Guideline estimated the costs associated with the production of carbon dioxide $\left(\mathrm{CO}_{2}\right)$ in $0.0088 \mathrm{US} \$ / \mathrm{kg}$, of sulphur dioxide $\left(\mathrm{SO}_{2}\right)$ in $1.65 \mathrm{US} \$ / \mathrm{kg}$, and of nitrogen oxides $\left(\mathrm{NO}_{\mathrm{x}}\right)$ in 7.48 US\$/kg (Effert, and Thompson, 2000).

If the environmental benefits due to the no emissions of polluting substances was considered in the economic analysis, the economic benefit would be 13,000 US $\$$ /year only for the absence of emitted $\mathrm{NO}_{\mathrm{x}}$ in a $10 \mathrm{~kW}_{\mathrm{p}}$ plant, as it results by combining the environmental studies of Kroposki and De Blasio (2000) and the economic studies of the Denver Service Guideline.

The objective of this work was the development of a new version of the software Solar in which is contained the instruments to conduce the economic analysis of PV system.

The software can be update in future with the introduction of new archives for the selection of the devices necessary for the plant. So, it will can be inserted an archive with the models of batteries and one with the models of inverters.

In the software can also be inserted a function that considers the benefit of the no emission in the economic analysis.

Another upgrade that can be done is a technical function that premise to operate the calculation relative to the modules connection. Knowing the values of wanted power, voltage and current, through this function it is possible to find the number of the modules branch in parallel and the number of modules connected in series in each branch.

\section{REFERENCES}

Bailey, B., Perez, R., Doty, J., Elsholz, K., Stewart, R., and Huse, W., 1991, Early Experiences of the $15 \mathrm{~kW}$ NMPC Demand-side Management Photovoltaic Project, Solar Cells, Vol. 30, No. 1-4, pp. 529-533.

Barra, O. A., 1981, The Photothermal Conversion of Solar Energy: Design and Research of Plants and Solar Systems, Etas Libri. [in Italian]

Chendo, M. A. C. and Salawu, R. I., 1989, Design Considerations of a Total Energy Power System for a Rural Health Centre in Nigeria, Solar \& Wind Technology, Vol. 6, No. 6, pp. 747-754.

De Groot, P., 1997, A Photovoltaic Project in Rural Africa: A Case Study, Renewable Energy, Vol. 10, No. 2-3, pp. 163-168.

Delahoy, A. E. and Kiss, Z. J., 2000, Photovoltaics: Heading Towards Thin Film, Energy Photovoltaic, Inc. 
Dhere, N. G., 1989, The Development of Solar Photovoltaic Energy in Brazil, Solar Cells, Vol. 26, No. 1-2, pp. 13-23.

Effert, P. and Thompson, A., 2000, U.S. Guidelines the Economic Analysis of Buildingintegrated Photovoltaic Power Systems, NREL National Renewable Energy Laboratory, TP 71025266.

Empresa de Pesquisa Energetica (Brazil), 2008, Brazilian Energy Balance 2008: year 2007, Empresa de Pesquisa Energetica.

Erge, T., Hoffmann, V. U., and Kiefer, K., 2001, The German Experience with Grid-connected PV Systems, Solar Energy, Vol. 70, pp. 479-487.

Harford, J. R. J., 1998, BP Solar and Photovoltaic Projects: A Case Study Health Centre Rehabilitation Project in Zambia, Renewable Energy, Vol. 15, No. 1-4, pp. 491-495.

Italian National Agency for New

Technologies, Energy and Sustainable Economic Development (ENEA), 2002a, The Photovoltaic Energy, ENEA. [in Italian]

Italian National Agency for New Technologies, Energy and Sustainable Economic Development (ENEA), Photovoltaic Roof, 2002b, ENEA. [in Italian]

Kraemer, S. F., 1980, Solar Law: Present and Future, with Proposed Forms, Shepard's Inc.

Kreider, J. F., 1981, The Solar Heating Design Process, McGraw-Hill.

Kreith, F. and Kreider, J. F., 1976, Preliminary Design and Economic Analysis of Solar-energy Systems for Heating and Cooling of Buildings, Energy (UK), Vol. 1, pp. 63-76.

Kreider, J. F. and Kreith, F., 1977, Solar Heating and Cooling: Engineering Practical Design and Economics, Hemisphere Publishing Corporation.

Kreider, J F. and Kreith, F. (eds.), 1981, Solar Energy Handbook, McGraw-Hill.

Kroposki, B. E. and De Blasio, R., 2000, Technologies for the New Millennium: Photovoltaics as a Distributed Resource, in: NREL - National Renewable Energy Laboratory, IEEE Power Engineering Society (PES), Seattle, Washington, July 16-20.

Leitch, A. W. R. and Van Der Linde, H. A., 1995, A Photovoltaic Project for the Rural Areas of the Eastern Cape, South Africa, Renewable Energy, Vol. 6, No. 5-6, pp. 549-551.

Mortensen, J., 2001, Factors Associated with Photovoltaic System Cost, NREL - National Renewable Energy Laboratory, TP 620-29649.

National Renewable Energy Laboratory (USA), 2009, Solar Research, National Renewable Energy Laboratory.

Ruther, R., 1998, Solar Photovoltaic into Buildings Integrated to Public Power Grid, UFSC/DEM/LABSOLAR. [in Portuguese]

Silveira, J. L., 1994, Cogeneration Disseminated to Small Users: A Case Study for the
Tertiary Sector, Doctoral Thesis, University of Campinas, Campinas, SP, Brazil. [in Portuguese]

Silveira, J. L., Walter, A. C. S., Luengo, C. A., 1995, Cogeneration for Small User: Case Studies for Brazilian Tertiary Sector, in: ASME Cogen Turbo Power Conference, Vienna, Austria.

Song, J., 1994, Recent Progress in National Photovoltaic Project in Korea, Solar Energy Materials and Solar Cells, Vol. 34, No. 1-4, pp. 5156.

Valente, L. C. G. and Almeida, S. C. A., 1998, Economic Analysis of a Diesel-Photovoltaic Hybrid System for Decentralized Power in Northern Brazil, Energy Journal, Vol. 23, No. 4, pp. 317-23.

Workgroup on Solar Energy (GTES), 1999, Engineering Guide for Photovoltaic Systems, CEPEL-CRESESB. [in Portuguese]

Received: June 09, 2009

Revised: July 09, 2009

Accepted: August 09, 2009 